\title{
Epidemiology of asthma and allergic diseases in Portuguese speaking regions
}

\section{Épidémiologie de l'asthme et des allergies dans les pays de langue portugaise}

\author{
J. Rosado-Pinto *, A. Gaspar, M. Morais-Almeida \\ Serviço de imunoalergologia, hospital Dona Estefânia, rua Jacinta Marto, Lisboa, Portugal \\ Received 9 January 2006; accepted 12 January 2006 \\ Available online 10 March 2006
}

\begin{abstract}
The application of the same epidemiological methods in different countries allows important comparisons between different races and cultures. During the last decade, two large multi-centres epidemiological studies, the Portuguese Study of Allergic Diseases in Childhood (PAC study) and the International Study of Asthma and Allergies in Childhood (ISAAC study), were implemented in Portuguese speaking regions. The main objectives were to assess and compare allergic diseases prevalence. The authors stress out the significant differences observed in schoolchildren from the three continents, with different genetic and environmental background. It was found an increase trend in the prevalence of all allergic diseases, mainly rhinitis, in last decade. Rhinitis has been identified as an independent risk factor for asthma in Caucasian population. (C) 2006 Elsevier SAS. All rights reserved.
\end{abstract}

\section{Résumé}

L'application des mêmes méthodes épidémiologiques dans plusieurs pays permet des comparaisons importantes entre des différentes races et cultures. Pendant la dernière décennie, deux centres majeurs d'études épidémiologiques, Portuguese Study of Allergic Diseases in Childhood (étude PAC) et International Study of Asthma and Allergies in Childhood (étude ISAAC), furent implantés dans des régions de langue portugaise. Les objectifs principaux furent de mesurer et comparer la prévalence de maladies allergiques. Les auteurs ont observé des différences significatives chez les enfants étudiés dans les trois continents, avec des influences génétiques et environnementales différentes. On a trouvé une tendance à l'augmentation de la prévalence de toutes les maladies allergiques, principalement de la rhinite, pendant la dernière décennie. La rhinite a été identifiée comme étant un facteur indépendant de risque pour l'asthme au sein de la population caucasienne.

(C) 2006 Elsevier SAS. All rights reserved.

Keywords: Asthma; Allergic rhinitis; Prevalence; Lifestyle; Environment

Mots clés : Asthme ; Rhinite allergique ; Prévalence ; Mode de vie ; Environnement

\section{Introduction}

In the last decades there has been a worldwide increase of allergic diseases, making them a priority to all the health care systems $[1,2]$. Bronchial asthma represents an important health problem related with significant impact in terms of morbidity

\footnotetext{
${ }^{*}$ Corresponding author.

E-mail address: hde.imunoalergo@mail.telepac.pt (J. Rosado-Pinto).
}

and mortality, being with allergic rhinitis, the most frequent childhood chronic diseases, showing also a prevalence increase as well in developed, as in developing countries [3,4]. Asthma and rhinitis are common co-morbidities [1], although the nature of the association is still not well known. Allergic rhinitis is frequently underestimated and undertreated, with important repercussions in quality of life, affecting school performance in children.

In 1992 two different epidemiological studies, under the responsibility of our group, started in the Portuguese speaking 
regions of Portugal (Europe), Cape Verde (Africa) and Macao (Asia): the global International Study of Asthma and Allergies in Childhood (ISAAC) and the Portuguese Study of Allergic Diseases in Childhood (PAC). In these two studies, involving a large group of investigators, performed during 10 years, we analysed epidemiological data collected from Portuguese official language regions with different genetic, cultural and environmental influences.

Coincident with the application of ISAAC study, from Phases I to III, the authors also performed, in Lisbon, a prospective study, in order to evaluate and correlate the impact of allergic rhinitis in clinical outcome of childhood recurrent wheezing.

\section{The PAC study}

This study was performed in different Portuguese speaking regions $[5,6]$. The aims, similar to those described in ISAAC, were mainly to assess atopy and allergic diseases prevalence and to obtain baseline measure for future comparisons. Randomly samples of schoolchildren from Madeira, Cape Verde and Macao, were included, studied with the same methodology:

- investigator-applied standard questionnaire, based on ISAAC;

- skin prick tests (standardised allergen extracts to common inhalant allergens: house-dust mites, cockroaches, moulds, pets and pollens, supplied by Merck-Allergopharma and CBF-Leti);

- bronchial provocation test with methacholine (Lofarma) for the characterisation of bronchial hyperreactivity, performed among those who had asthma symptoms in the last year, and in matched controls (age and sex).

Definitions: Atopy - at least one positive skin prick test (wheal greater than $7 \mathrm{~mm}^{2}$ ); Positive bronchial hyperreactivity $-\mathrm{PD}_{20} \mathrm{FEV}_{1}$ methacholine lower than $7.8 \mu \mathrm{mol}$; Active disease - symptoms last year; Current asthma - positive bronchial test and active asthma.

In 1993, in Sal Island, were studied 235 children aged 616 years, mostly of them Black African; in 1994, a sample of 588 children, aged 6-10 years, was included in S. Vicente Island, mostly of them Creoles (these two islands belongs to the archipelago of Cape Verde, an African country in the Gulf of Guinea). In 1995, 1061 Caucasian children aged 6-10 years were studied in Madeira Island (Portugal). In 1997, 1385 Chinese children aged 6-12 years, were studied in Macao (territory located on the Southern Coast of China, under Portuguese administration until 1999).

The analysis of the results, revealed significant differences of atopy and allergic diseases prevalence in the populations studied. In Madeira [7], we found the highest prevalence of atopy $(54 \%)$, active asthma (14.6\%) and current asthma $(10.2 \%)$ (Table 1).

In Macao, according to the atopic status of the population (48.6\%), the extremely low prevalence of active asthma (1.3\%) and ever asthma (3.5\%) was not expected [8], being similar to
Table 1

PAC study-atopy and asthma prevalence (\%)

\begin{tabular}{lllll}
\hline $\begin{array}{l}\text { Country } \\
\text { Region }\end{array}$ & $N$ & Atopy & $\begin{array}{l}\text { Active } \\
\text { asthma }\end{array}$ & $\begin{array}{l}\text { Current } \\
\text { asthma }\end{array}$ \\
\hline $\begin{array}{l}\text { Cape Verde } \\
\text { Sal }\end{array}$ & 235 & 6.0 & 10.6 & 2.6 \\
$\begin{array}{l}\text { S. Vicente } \\
\begin{array}{l}\text { Portugal } \\
\text { Madeira }\end{array}\end{array}$ & 588 & 11.9 & 7.0 & 4.8 \\
$\begin{array}{l}\text { China } \\
\text { Macao }\end{array}$ & 1061 & 54.1 & 14.6 & 10.2 \\
\hline
\end{tabular}

a SPT performed only in a randomly sub-sample of 743 children.

data published by Leung et al. [9] in San Bu, China, sharing the same ethnic background, but much lower than the rates found in Hong Kong. Most asthmatic children had atopy $(86 \%)$ and had a positive methacholine challenge test $(88 \%)$. In contrast, the higher rhinitis prevalence found (24.8\%), was quite similar to those identified in Hong Kong and Madeira (22\%), and much higher than the rates in China. In addition to atopy, other risk factors, as lifestyle, should be important on allergic disease expression in these regions. We showed that it is possible to have a very strong expression of atopy with very low asthma prevalence. Comparing our data from Macao and Madeira, we found an 11-fold variation in active asthma prevalence (1.3 vs. $14.6 \%$ ), but also a 20 -fold variation in maternal smoking $(0.5$ vs. $10 \%)$. The importance of passive tobacco smoke exposure in childhood is well known.

In Cape Verde [10], active asthma had a similar prevalence to most European countries, but much lower prevalence of allergen sensitisation. Different wheezing phenotypes could be implicated, even in 6-16-year-old patients, and recurrent respiratory infections may play a major role. The low prevalence of atopy in Cape Verde was not related with lower allergen exposure [5]. The high mean value of serum total $\operatorname{IgE}$ found in Cape Verde, even in non-atopic individuals, probably related to the parasite load of this population, could be important on the modulation of the allergic response [11]. The different results found in the two Cape Verde Islands studied, namely the differences of atopy and current asthma, with important ethnic variations, point out the importance of genetics.

In order to assess trends in the prevalence of atopy and allergic diseases in Cape Verde, in 1999, it was randomly selected in Sal Island a new sample of 175 children aged 610 years [6]; the epidemiological methods were the same and it was possible to correlate the results with those obtained in the same age group 6 years earlier. The atopy prevalence raised threefolds (6 to $18 \%$ ) and the allergic rhinitis prevalence (symptoms last year) doubled from 11 to $22 \%$. The prevalence of active asthma was unchanged (15 to $16 \%$ ) but the prevalence of atopic asthma (asthmatics with positive skin prick tests) raised from 2 to $5 \%$. That is probably the price paid for progress, related with the improved Capeverdian population well being.

\section{The ISAAC study}

This study was performed under the national coordination of José Rosado-Pinto, by questionnaire modules, in several re- 
gions of Portugal, between 1993 and 2002, involving more than 40,000 schoolchildren of two age groups: 6-7 and 1314 years old [12]. The objectives of this international study $[3,13]$, not yet completely published, and divided into three phases were:

- to describe the prevalence and severity of allergic diseases in children living in different places, allowing comparisons within and between countries;

- to obtain baseline measures for the assessment of future trends in allergic diseases prevalence and severity;

- to provide a framework for further etiological research into lifestyle, environmental, genetic and health care factors affecting these diseases.

In Portugal, this study involved in Phase I 207 schools for 6-7 years old and 84 for 13-14 years old and in Phase III 408 and 142 schools, respectively, for the same age groups [12].

Comparing the data obtained in Phase I and Phase III (Tables 2 and 3)-(data on file), we found a statistically significant increasing trend in rhinitis (cumulative and last year symptoms) and eczema (last year) prevalence, for both the age groups studied. Regarding the last year wheezing prevalence, in the group of 6-7 years, 9 years later we found the same prevalence $12.9 \%$, but in the $13-14$ years group we found a statistically significant increasing from 9.2 to $11.8 \%$, particularly in the two urban regions corresponding to the Portuguese largest cities: Lisbon $(10.9$ to $14.6 \% ; P<0.001)$ and Oporto ( 7.2 to $13.1 \% ; P<0.001)$. The same trend was found,

Table 2

ISAAC study in Portugal-allergic diseases prevalence in 6-7-year-old children

\begin{tabular}{|c|c|c|c|c|c|}
\hline \multirow[t]{2}{*}{ Allergic diseases prevalence } & \multicolumn{2}{|c|}{$\begin{array}{c}\text { Phase I } \\
(1993 / 1994)\end{array}$} & \multicolumn{2}{|c|}{$\begin{array}{c}\text { Phase III } \\
(2002)\end{array}$} & \multirow[t]{2}{*}{$P$-value } \\
\hline & $\bar{N}$ & $\%$ & $\bar{N}$ & $\%$ & \\
\hline \multicolumn{6}{|l|}{ Wheezing } \\
\hline Wheezing ever & 1420 & 28.2 & 1512 & 28.1 & 0.94 \\
\hline Wheezing last year & 649 & 12.9 & 692 & 12.9 & 0.98 \\
\hline \multicolumn{6}{|l|}{ Rhinitis } \\
\hline Rhinitis ever & 1198 & 23.8 & 1565 & 29.1 & $<0.001$ \\
\hline Rhinitis last year & 1003 & 19.9 & 1291 & 24.0 & $<0.001$ \\
\hline \multicolumn{6}{|l|}{ Eczema } \\
\hline Eczema ever & 938 & 18.6 & 1129 & 21.0 & 0.002 \\
\hline Eczema last year & 698 & 13.9 & 838 & 15.6 & 0.013 \\
\hline
\end{tabular}

Table 3

ISAAC study in Portugal-allergic diseases prevalence in 13-14-year-old children

\begin{tabular}{|c|c|c|c|c|c|}
\hline \multirow[t]{2}{*}{ Allergic diseases prevalence } & \multicolumn{2}{|c|}{$\begin{array}{c}\text { Phase I } \\
(1993 / 1994)\end{array}$} & \multicolumn{2}{|c|}{$\begin{array}{l}\text { Phase III } \\
(2002)\end{array}$} & \multirow[t]{2}{*}{$P$-value } \\
\hline & $\bar{N}$ & $\%$ & $\bar{N}$ & $\%$ & \\
\hline \multicolumn{6}{|l|}{ Wheezing } \\
\hline Wheezing ever & 2082 & 18.2 & 2576 & 21.8 & $<0.001$ \\
\hline Wheezing last year & 1049 & 9.2 & 1398 & 11.8 & $<0.001$ \\
\hline \multicolumn{6}{|l|}{ Rhinitis } \\
\hline Rhinitis ever & 3455 & 30.2 & 4383 & 37.1 & $<0.001$ \\
\hline Rhinitis last year & 2417 & 21.2 & 3131 & 26.5 & $<0.001$ \\
\hline \multicolumn{6}{|l|}{ Eczema } \\
\hline Eczema ever & 1460 & 12.8 & 1573 & 13.3 & 0.22 \\
\hline Eczema last year & 869 & 7.6 & 1032 & 8.7 & 0.002 \\
\hline
\end{tabular}

in the 13-14 years group, in the cumulative prevalence of wheezing, from 18.2 to $21.8 \%$.

In the ISAAC Phase III, the questionnaire included several lifestyle items. The most relevant results at national level referred in the 13-14 years age group were: fast-food once a week or more in $49 \%$; physical activities three or more times a week in only $22.5 \% ; 3$ or more hours/day watching TV in $52.2 \%$; no smoker at home in only $34.3 \%$ (father smoking in $42.3 \%$, and mother smoking in $22.8 \%$ ).

\section{The prospective study of risk factors for active asthma at school age}

The authors [14] performed an 8-year prospective study, in order to correlate clinical outcome of recurrent wheezing in the first years of life with prognostic risk factors, including evaluation of the impact of allergic rhinitis. A cohort of 308 children with recurrent wheezing, aged less than 7 years, was enrolled in 1993, studied with clinical questionnaire (adapted from ISAAC), skin prick tests (standardised allergen extracts to common inhalant allergens, house-dust mites, pollens, moulds, cockroaches and pets supplied by Merck-AlIergopharma and CBF-Leti, and food allergens, cow's milk proteins, egg, fish and wheat supplied by Stallergènes), and serum total IgE. Eight years later, it was possible to re-evaluate $81 \%$ of the initial sample $(N=249)$, repeating skin prick tests and performing lung function tests (spirometry with assessment of bronchodilator response).

By logistic regression analysis, personal history of allergic rhinitis was identified as an independent risk factor for active asthma at school age, with an adjusted odds ratio of $15.8(95 \%$ $\mathrm{CI}=6.1-40.8)$. In the children with allergic rhinitis, $85 \%$ had active asthma, compared to $21 \%$ of those without rhinitis $(P<0.001)$. Similar results were found, in adults, by other authors. Leynaert et al. [15], by investigating cross-sectional data from the European Community Respiratory Health Survey, found an adjusted odds ratio for association between rhinitis and asthma of 8.1 among atopic and 11.6 among non-atopic subjects 20-40 years old. Guerra et al. [16], using data that was collected as part of the Tucson Epidemiologic Study of Obstructive Lung Diseases, identified rhinitis as a significant and independent risk factor for adult-onset asthma, with an odds ratio of 4.13. There is certainly more than just a causal relation between asthma and rhinitis, but it is yet to be determined if asthma is the natural progression of a common airway disease.

\section{Conclusion}

The significant differences found in atopy and allergic diseases prevalence in schoolchildren populations from African, Asiatic and European Portuguese speaking regions studied in the PAC study, point out the importance of genetics, linked to race, in the pathogenesis of these diseases, although it will be strongly modulated by environmental and lifestyle variables.

Comparing the results obtained from Phase I and Phase III of ISAAC study in Portuguese schoolchildren, an increasing 
trend in the prevalence of all allergic diseases during the last decade was revealed, mainly in relation to rhinitis in both age groups studied, with a slight increase also in asthma and atopic eczema symptoms during the last year. Some lifestyle changes in our children, such as western diet habits, absence of physical activities, high indoor habits (watching TV or playing with computer) and tobacco smoke exposure, seem to play a role.

Early diagnosis of bronchial asthma is important to plan adequate treatment and prevention. Although several clinical studies suggest that upper respiratory tract dysfunction may affect the lower airways, the diagnosis of rhinitis is frequently underestimated by non-specialist physicians, namely in paediatric age. The authors have identified rhinitis as an independent risk factor for asthma in Caucasian population.

The worldwide increasing of asthma and allergic diseases observed in the last decades demands for a global health strategy [1-3]. As a consequence of these large epidemiological projects, it will be possible to plan health care programs at national and international levels for better prevention, education and treatment of allergic diseases, whose direct and indirect costs will certainly strongly increase in this Century.

\section{References}

[1] Bousquet J, Van Cauwenberge P, Khaltaev N, Aria Workshop Group, World Health Organization. Allergic rhinitis and its impact on asthma. J Allergy Clin Immunol 2001;108(Suppl. 5):147-334.

[2] Global Strategy for Asthma Management and Prevention. National Institutes of Health, National Heart, Lung, and Blood Institute. Guidelines for the diagnosis and management of asthma, NIH, Publication Number 023659; 2002.

[3] ISAAC Steering Committee. Worldwide variation in prevalence of symptoms of asthma, allergic rhinoconjunctivitis, and atopic eczema: ISAAC. Lancet 1998;351:1225-32.
[4] Bousquet J, Ndiaye M, Ait-Khaled N, Annesi-Maesano I, Vignola AM. Management of chronic respiratory and allergic diseases in developing countries. Focus on sub-Saharan Africa. Allergy 2003;58:265-83.

[5] Morais Almeida M, Rosado Pinto J. Bronchial asthma in children: clinical and epidemiologic approach in different Portuguese speaking countries. Pediatr Pulmonol Suppl 1999;18:49-53.

[6] Morais Almeida M, Gaspar A, Rosado Pinto J. Epidemiology of asthma in Portugal, Cape Verde and Macao. Pediatr Pulmonol 2001(Suppl. 23): 35-7.

[7] Morais Almeida M, Câmara R, Marques A, Ornelas P, Romeira J, Neuparth N, et al. Prevalence of asthma and atopy in Madeira Archipelago schoolchildren. Eur Respir J 1996;9(Suppl. 23):232s.

[8] Morais Almeida M, Andrade I, Ieong KM, Gaspar A, Andrade N, Humberto $\mathrm{J}$, et al. Epidemiology of childhood allergic diseases and atopy in Macau (Southern Coast of China). Eur Respir J 1998;12(Suppl. 28):13s.

[9] Leung R, Ho P, Lam CWK, Lai CKW. Sensitization to inhaled allergens as a risk factor for asthma and allergic diseases in Chinese population. J Allergy Clin Immunol 1997;99:594-9.

[10] Neuparth N, Morais Almeida M, Santa Marta C, Pires G, Vieira Lopes D, Tavares C, et al. Prevalence of childhood asthma and atopy in Cape Verde: preliminary results. Eur Respir J 1995;8(Suppl. 19):495s.

[11] Abreu Nogueira JM, Pinto PL, Morais Almeida M, Tavares C, Lopes D, Loureiro V, et al. Alatop-RIA in the screening of atopy in a non Caucasian population. Allerg Immunol (Paris) 1997;9:274-8.

[12] Nunes C, Ladeira S, Rosado Pinto J. Definição, epidemiologia e classificação da asma na criança. In: Rosado Pinto J, Morais de Almeida M, editors. A criança asmática no mundo da alergia. Lisboa: Euromédice; 2003. p. 35-56.

[13] Asher MI, Keil U, Anderson HR, Beasley R, Crane J, Martinez F, et al. International study of asthma and allergies in childhood (ISAAC). Rationale and methods. Eur Respir J 1995;8:483-91.

[14] Morais-Almeida M, Gaspar A, Rosado-Pinto J. Risk factors for active asthma at school age: an 8-year prospective study. Allergy Asthma Proc 2006 (in press).

[15] Leynaert B, Bousquet J, Neukirch C, Liard R, Neukirch F. Perennial rhinitis: an independent risk factor for asthma in nonatopic subjects: results from the European Community Respiratory Health Survey. J Allergy Clin Immunol 1999;104:301-4.

[16] Guerra S, Sherrill DL, Martinez FD, Barbee RA. Rhinitis as an independent risk factor for adult-onset asthma. J Allergy Clin Immunol 2002; 109:419-25. 